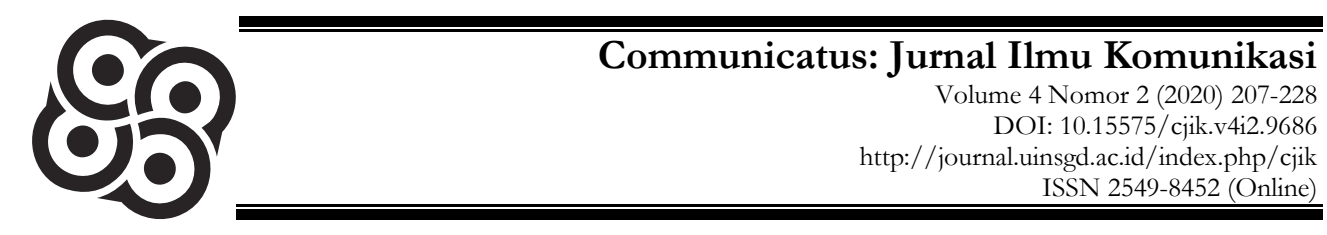

\title{
Rebel Together Sebagai Strategi Komunikasi Pemasaran Digital Madformakeup di Tengah Pandemi COVID-19
}

\author{
Indri Julianti ${ }^{1} \&$ Santi Delliana ${ }^{2 *}$ \\ ${ }^{1,2}$ Institut Teknologi dan Bisnis Kalbis \\ *email: anastasia.santi@kalbis.ac.id
}

\begin{abstract}
The appearance of virus COVID-19 pandemic has made businesses change their marketing communication strategic ways to survive in this pandemic, including makeup companies like Madformakeup. One of the strategies used by Madfromakeup is planning a fair and effective digital marketing communication strategy and implementing customer engagement through the Rebel Together program. This study aims to determine the digital marketing communication strategy adopted by Madformakeup in increasing sales during the COVID-19 pandemic. The method that the researcher used is a qualitative method with the type of descriptive research. The results of this study are that Madformakeup implemented a digital marketing communication strategy during the COVID-19 pandemic so well and effectively through the STP and IMC concepts. To produce a digital marketing communication strategy that can be accepted by the public, especially customers from Madformakeup. Researchers collected data through interviews, observation, and documentation in the form of photos.
\end{abstract}

Keywords: Rebel Together, Communication Strategy, Digital Marketing, Madformakeup, Pandemic.

\section{ABSTRAK}

Penelitian ini bertujuan untuk mengetahui strategi komunikasi pemasaran digital yang diterapkan oleh Madformakeup dalam meningkatkan penjualan selama pandemi covid19. Adanya pandemi covid-19 ini menimbulkan perubahan strategi komunikasi pemasaran bagi para pelaku bisnis untuk tetap bertahan di tengah pandemi, termasuk perusahan makeup yaitu Madformakeup. Salah satu strategi yang digunakan Madformakeup adalah perencanaan strategi komunikasi pemasaran digital yang baik dan efektif, dengan menerapkan customer engagement melalui program Rebel Together. Metode penelitian yang digunakan adalah metode kualitatif dengan jenis penelitan deskriptif dengan memilih dua informan kunci dan satu informan pendukung dari pelanggan Madformakeup. Hasil penelitian ini adalah bahwa Madformakeup menerapkan strategi komunikasi pemasaran digital selama pandemi covid-19 ini dengan baik dan efektif melalui konsep STP dan IMC sehingga menghasilkan strategi komunikasi pemasaran digital yang dapat diterima oleh customer Madformakeup. Peneliti melakukan pengumpulan data dengan wawancara, observasi, dan dokumentasi berupa foto.

Kata kunci : Rebel Together, Strategi Komunikasi, Pemasaran Digital, Madformakeup, Pandemi Covid19. 


\section{PENDAHULUAN}

Setiap pelaku bisnis khususnya di bidang komestik dalam memasarkan produk ataupun jasa memiliki strategi komunikasi pemasaran yang berbeda-beda. Berdasarkan data dari Kementerian Perindustrian Republik Indonesia bahwa industri kosmetik pada tahun 2019 mengalami pertumbuhan 7\%, lalu di tahun 2020 Kementrian Perindustrian Republik Indonesia menargetkan industri kosmetik naik hingga 9\% (Kemenperin, 2020). Dengan adanya persaingan di dunia industri kosmetik perusahaan dituntut untuk melakukan penerapan strategi komunikasi pemasaran yang efektif untuk menarik customer engagement dalam meningkatkan penjualan dan dapat dikenal masyarakat, oleh karena itu para pelaku usaha melakukan berbagai cara atau strategi untuk mempertahankan suatu kegiatan dari persaingan bisnis.

Namun fenomena virus covid-19 muncul di seluruh dunia termasuk Indonesia, dengan adanya virus covid-19 memberikan dampak negatif terhadap kondisi ekonomi Indonesia khususnya sektor FMCG (Fast Moving Consumer Goods). Menurut data dari SurveySensum dan NeuroSensum, perusahaan konsumen FMCG turut mengalami penurunan pendapatan sebesar 54\% (Jatmiko, 2020). Dengan adanya pandemi covid-19, penerapan strategi komunikasi pemasaran pelaku usaha bisnis pun saat ini berubah. Menurut Rajiv Lamba, CEO dari SurveySensum \& NeuroSensum adanya pandemi covid-19 sekitar 59\% para pelaku bisnis memfokuskan usahanya melalui e-commerce untuk meningkatkan penjualannya (Lalu, 2020). Saat pandemi covid-19, Madformakeup tetap menerapkan strategi komunikasi pemasaran untuk mempertahankan suatu bisnis. Penyebab masalah pandemi ini belum berakhir karena terjadinya pelonjakan penderita Covid-19 juga disebabkan oleh masih banyak anak muda yang tetap berkumpul di kafe. Penekanan persoalan ini juga dikuatkan dengan pernyataan tidak pentingnya budaya sosialisasi dan hangout yang selama ini dijalankan sebelum masa pandemi (Boer et al., 2020).

Pengelolaan komunikasi pemasaran dibutuhkan suatu strategi, Madformakeup membuat strategi dengan menerapkan customer engagement melalui program Rebel Together hal ini dapat digunakan demi meningkatkan penjualan. Strategi memang dinilai menjadi salah satu hal terpenting dalam membangun bisnis, dalam hal ini Madformakeup memanfaatkan internet seperti Instagram dan e-commerce sebagai platform untuk memperkenalkan produk terbaru serta dapat berinteraksi dengan pelanggannya. Mulai sekitar tahun 2009, media sosial mengalami emas usia. Media sosial bermetamorfosis menjadi alat yang sangat potensial di Indonesia, yang dapat dipergunakan juga untuk berinteraksi dengan para pelanggan (Delliana \& Wibowo, 2019).

Berdasarkan data dari ZAP Beauty Index, Dr. Dara mengatakan bahwa $65,4 \%$ wanita Indonesia memperhatikan keamanan produk seperti memiliki label BPOM, selain itu ulasan produk kecantikan sebesar 64,7\% dapat memberikan 
dampak pada wanita dalam memutuskan membeli sebuah produk kecantikan. Hal ini sangat berpengaruh pada generasi Z rentang usia 13-22 Tahun (Putri, 2020).

Penelitian yang dilakukan oleh Theresiana \& Setyanto (2018) Guten Morgen Coffee Lab and Shop ingin menyampaikan kepada customer bahwa coffee ini memiliki keunikan yaitu dengan adanya latar belakang dalam memperkejakan barista yaitu mantan pecandu narkoba. Mengenai penelitian terdahulu ini adanya kemiripan dengan penulis yaitu menggunakan pendekatan secara kualitatif deskriptif yang di mana menggunakan STP (segmentasi, target, dan promosi) sebagai bagian dari penelitian dalam strategi komunikasi pemasaran. Bukan hanya itu, persamaan antara penelitian terdahulu ini dengan penelitian yang diteliti penulis, yaitu sama-sama menggunakan aspek promotional mix, Namun dalam hal ini, adanya perbedaan diantara penelitian terdahulu oleh Leanora Theresiana dengan penelitian yang diteliti penulis, yaitu ketika penelitian terdahulu ini mengambil Morgen Coffee Lab and Shop sebagai objek yang diteliti, sedangankan penulis meneliti strategi komunikasi pemasaran digital terhadap objek Madformakeup. Hal ini tentu berada di wilayah yang berbeda, yaitu Madformakeup yang berada di wilayah pemasaran kosmetik sedangkan Morgen Coffee Lab and Shop wilayah pemasaran kuliner.

Penelitian terdahulu pertama dilaksanakan oleh Afrilia (2018) dari Universitar Tidar pada tahun 2018 yang berjudul "Digital Marketing sebagai Strategi Komunikasi Pemasaran "Waroenk Ora Umum” dalam Meningkatkan Jumlah Konsumen. Penelitian ini menggambarkan strategi kounikasi pemasaran digital yang di lakukan oleh Waorenk Ora Umum yang berlokasi di Purwokerto untuk meningkatkan jumlah konsumen. Dalam penelitian ini menggunakan penelitian kualitatif deskriptif untuk menggambarkan penerapan strategi komunikasi pemasaran digital yang digunakan oleh Waroen Ora Umum serta pengambilan teknik data melalui observasi, wawancara, dan dokumenter. Mengenai hal ini, terjadi persamaan dengan penelitian penulis yaitu menggunakan metode penelitian serta teknik pengumpulan data yang sama. Penggunaan strategi pemasaran yang mengarah pada segmentasi, targetting, dan positioning juga merupakan pembahasan yang dianalisis oleh Ascharisa Mettasatya Afrilia. Meskipun penelitian terdahulu maupun penulis mengambil ranah yang sama mengenai strategi komunikasi pemasaran. Namun terdapat perbedaan yaitu objek yang di ambil, pada penelitian terdahulu objek yang diambil yaitu Waroenk Ora Umum sedangkan penulis mengambil Madformakeup sebagai objek penelitian. Dalam hal ini terdapat perbedaan dalam arah pangsa pasar, yaitu bisnis kosmetik dan bisnis kuliner. Penelitian terhadap Waroenk Ora Umum memfokuskan STP dan digital marketing hanya melalui social media Instagram. Sedangkan penulis mengambil STP dan konsep integrated marketing communication (Promotional Mix: Tools IMC) sebagai promosi yang digunakan Madformakeup melalui digital marketing Instagram dan E-commerce. 
Sejalan dengan Teguh et al. (2020) kegiatan IMC ini dilakukan mengingat kedua jenis target tersebut dapat dicapai dengan teknik STP dan menjalin hubungan baik melalui kegiatan promosi penjualan dan pemasaran langsung. Sedangkan bagi konsumen langsung, kegiatan promosi yang lebih bervariatif menggugah kesadaran dan mendorong pembelian. Ada satu jenis promosi yang diberikan kepada pembeli dan pengguna akhir yaitu komunikasi pemasaran digital.

Berdasarkan fenomena yang terjadi, Kemenperin menargetkan industri kosmetik mengalami peningkatan di tahun 2020, namun muncul pandemi covid19 yang memberikan dampak buruk bagi ekonomi Indonesia termasuk sektor FMCG yang di mana kosmetik termasuk dalamnya. Adanya pandemi covid-19 strategi komunikasi pemasaran yang digunakan oleh para pelaku bisnis berubah dengan memanfaatkan e-commerce. Strategi komunikasi pemasaran tentu dibutuhkan oleh perusahaan untuk mempengaruhi perilaku customer engagement melalui program Rebel Together dalam meningkatkan penjualan serta mempertahankan suatu bisnis selama pandemi covid-19. Madformakeup memiliki strategi dalam memasarkan produk, menyampaikan pesan yang unik sehingga mendapatkan ulasan yang positif dari customer. Maka dari itu peneliti tertarik untuk mendeskripsikan bagaimana Rebel Together sebagai strategi komunikasi pemasaran digital yang dilakukan oleh Madformakeup selama pandemi covid-19.

Berdasarkan hal tersebut, maka rumusan masalah yang diangkat adalah bagaimana Rebel Together sebagai strategi komunikasi pemasaran digital Madformakeup di tengah pandemi covid-19. Berdasarkan permasalahan yang telah disebutkan, maka tujuan penelitian yang hendak dicapai yaitu untuk menggambarkan tentang bagaimana penerapan Rebel Together sebagai strategi komunikasi pemasaran digital Madformakeup di tengah pandemi covid-19.

Strategi Komunikasi Pemasaran

Menurut Rogers (Cangara, 2014, p. 64) strategi komunikasi merupakan suatu perancangan yang dibuat melalui ide-ide baru yang bertujuan untuk mengubah tingkah laku manusia dengan skala yang lebih besar. Dengan adanya strategi komunikasi yang terstruktur dan efisien maka akan mencapai suatu keefektivitasan. Menurut Middleton mengemukakan bahwa strategi komunikasi adalah adanya rancangan untuk mencapai tujuan komunikasi yang optimal dengan berbagai kombinasi dari semua elemen komunikasi mulai dari komunikator, pesan, saluran (media), penerima sampai pada pengaruh (efek).

Strategi Pemasaran (STP)

Tjiptono dan Chandra (Wardana, 2017, p. 162) dapat dikatakannya bahwa STP ini saling terkait dan menjadi salah satu faktor yang kuat dari strategi dari strategi pemasaran yang dapat dijabarkan, sebagai berikut yang pertama segmentasi. Proses pengelompokan dalam variabel yang bermacam-macam, dari segi demografis, psikografis, perilaku, pengambilan keputusan dan pola media pasar. Segmentasi sendiri juga mengelompokkan keseluruhan yang berbeda-beda 
ke dalam kelompok-kelompok yang sama dalam hal kebutuhan, keinginan, perilaku dan/atau respon terhadap program pemasaran spesifik.

Kedua adalah targeting, upaya strategi pemasarannya, targeting sendiri memiliki kriteria evaluasi yang meliputi ukuran dan potensi pertumbuhan segmen, karakteristik struktural segmen dan kesesuaian antara produk dan pasar. Dalam hal ini, targeting dapat dikatakan sebagai proses pengevaluasian dan memilih satu atau beberapa segmen pasar yang dinilai paling menarik untuk dilayani dengan program pemasaran spesifik perusahaan. Faktor ketiga yaitu positioning, upaya dalam menciptakan persepsi merek, produk maupun perusahaan yang unik dan unggul dalam sudut pandang konsumen. Di mana dalam konteks pemasaran adalah bagaimana suatu produk ditempatkan dalam benak konsumen dan dipersepsikan berbeda dengan produk, merek atau organisasi para pesaing.

\section{Integrated Marketing Communication}

Proses implementasi dilakukan dalam bentuk program persuasif ditujukan kepada pelanggan dan calon pelanggan secara berkelanjutan. Konsep IMC ini mencakup atas enam unsur yaitu the promotional mix: tool for IMC. Menurut George dan Belch (Morissan, 2010, p. 17) ada 6 elemen yang digunakan untuk kegiatan pemasaran dapat di jabarkan sebagai berikut: (1) Advertising/Iklan, penyajian atas promosi ideide serta promosi produk atau jasa yang dilakukan sponsor tertentu yang dibayar. Contohnya: iklan media cetak, iklan media elektronik, brosur, poster billboards, kemasan. (2) Sales Promotion (Promosi Penjualan), insentif jangka pendek, yang dimana untuk mendorongnya suatu keinginan dalam mencoba maupun membeli suatu produk atau jasa. Contohnya: undian, kontes, games, undian, kupon, pameran dagang. (3) Public Relation and Events (Humas/Acara), program yang dirancang untuk mempromosikan dan melindungi citra perusahaan atau produk individualnya. Contohnya: laporan tahunan, donasi, pidato, seminar, sponsorship, lobbying, events, majalah perusahaan. (4) Personall Selling, interaksi langsung dengan calon pembeli untuk melakukan suatu presentasi kepada target promosi serta menjawab langsung pertanyaan yang diajukannya. Contohnya: presentasi penjualan, produk sampel, pertemuan penjualan, pameran dagang. (5) Direct Marketing, penggunaannya telepon, e-mail, surat faksimili, dan alat penghubung nonpersonal lain untuk berkomunikasi serta mendapatkan tanggapan langsung dari pelanggan tertentu dan calon pelanggan. Contohnya: surat, telemarketing, katalog, voice mail, e-mail. (6) Interactive/Internet Marketing (Pemasaran Interaktif), pemanfaatan teknologi yang berkembang dengan pesat melalui internet yang dijadikan sebagai salah satu cara dalam penjualan dan pemromosian. Berdasarkan (Morissan, 2010, p. 24) media interaktif ini memungkinkannya terjadi arus informasi dan komunikasi yang cepat dan terdapatnya timbal balik yang memungkinkan pengguna dapat berpartisipasi isi informasi pada saat itu juga. Hal 
Indri Julianti \& Santi Delliana

ini dapat dikatakan pula bahwa internet ini merupakan media yang mencakup seluruh bauran promosi.

\section{Customer Engagement}

Menurut Willems (2011, p. 9) customer engagement merupakan proses untuk melibatkan konsumen pelanggan dengan cara berinteraksi di dalam sebuah dialog dan pengalaman yang bertujuan untuk mempengaruhi keputusan pelanggan dalam melakukan pembelian. Customer engagement adalah perilaku konsumen yang dapat memberikan voluntary contribution (konstribusi yang bersifat sukarela) bagi brand dalam sebuah perusahaan. Kontribusi tersebut bukan hanya dalam melakukan proses transaksi saja atau pembelian tetapi melakukan konstribusi seperti feedback memberikan saran atau ide, kontribusi dilakukan melalui WOM (word of mouth) dan lain lain (Jaakkola \& Alexander, 2014, p. 248). Sejalan dengan Andriansyah (2020) pada jangka panjang, Saddap akan menjangkau pelanggan secara lebih luas melalui alat komunikasi pemasaran yaitu pemasaran langsung, event pemasaran, dan penjualan langsung. Pada tahap ini Saddap diharapkan dapat memiliki saluran distribusi langsung yang memuat informasi dan penjualan langsung kepada pelanggan.

Pada penelitian ini peneliti menggunakan paradigma post-positivisme bertujuan untuk mengetahui klasifikasi dari perusahaan Madformakeup secara lebih mendalam mengenai strategi komunikasi pemasaran digital di tengah pandemi covid-19. Penelitian ini peneliti menggunakan pendekatan kualitatif dengan jenis penelitian deskriptif. Menurut Denzin dan Lincoln (Mulyadi, 2013, p. 49) penelitian kualitatif bertujuan untuk memaparkan pemahaman yang didasari melalui pengalaman tangan pertama, laporan sesungguhnya, dan percakapan yang konkrit.

Penelitian Rebel Together sebagai strategi komunikasi pemasaran digital Madformakeup di tengah pandemi ini, digunakannya teknik pemilihan informan yaitu sampling purposive atau pemilihan informan dengan tujuan tertentu. Adapun terdapat dua key informan dari penelitian ini yakni internal dari Madformakeup, yaitu: Tony Tan (Founder \& Business Development Manager) dan Damara (Marketing Communication). Peneliti juga menggunakan informan pendukung dari pelanggan Madformakeup, yaitu Daniella Mega Lestari (Pelanggan Madformakeup).

Peneliti menggunakan teknik pengumpulan data melalui wawancara, observasi, dan dokumentasi yang menurut Susan Stainback (Sugiyono, 2016, p. 232). Dalam penelitian ini menggunakan teknik analisis data Miles dan Hubberman (Sugiyono, 2016, p. 253) yaitu reduksi data, penyajian data, menurut Miles dan Huberman (Sugiyono, 2016, p. 249) proses penyajian data dapat dilakukan dalam bentuk uraian singkat, bagan, hubungan antara kategori, tetapi 
yang sering dipakai untuk menyajikan data dalam penelitian kualitatif adalah dengan teks yang bersifat naratif serta terakhir penarikan kesimpulan (verifikasi).

Menurut Wiliam Wiersma (Sugiyono, 2016, pp. 273-274) triangulasi adalah proses pengecekan data dari beberapa sumber dengan berbagai cara dan waktu. Peneliti menggunakan triangulasi sumber dengan membandingkan hasil wawancara dan hasil pengamatan melalui dokumen yang ada. Serta membandingkan apa yang dikatakan informan kunci dengan informan pendukung.

\section{HASIL DAN PEMBAHASAN}

Pengambilan data yang dilakukan peneliti melalui triangulasi sumber berupa wawancara dengan dua key informan, yaitu Tony selaku Business Development Manager Madformakeup dan Damara selaku Marketing Communication Madformakeup, Daniella Mega Lestari selaku customer Madformakeup sebagai informan pendukung. Pengambilan data dengan teknik dokumentasi dilakukan dengan mengambil unggahan gambar progam strategi komunikasi pemasaran, yaitu Rebel Together di Instagram@Madformakeup.co (Instagram Madformakeup, 2020). Teknik terakhir yang digunakan adalah observasi dengan mengamati penggunaan media sosial (a)Madformakeup.co selama pandemic covid-19 dalam lingkup Integrated Marketing Communicaton, Segmentasi, Targeting, Positioning (STP), dan Customer Engagement.

Penelitian ini melihat keterkaitan antara konsep strategi pemasaran terencana yang di kemukakan oleh Tjiptono dan Chandra dengan konsep aktivitas komunikasi pemasaran terpadu yang dikemukakan oleh Priansa dan Morrisan serta customer engagemet yang dikemukakan oleh Jaakkola dan Alexander (2014). Berdasarkan hasil wawancara dapat dijabarkan sebagai berikut: wawancara dilakukan oleh dua key informan yaitu; Tony selaku Business Development Manager Madformakeup dan Damara selaku Marketing Communication Madformakeup, Daniella Mega Lestari selaku customer Madformakeup sebagai informan pendukung.

Industri komestik di Indonesia terus berkembang, berkembangnya brand kosmestik membuat para pelaku usaha harus memiliki sebuah kesan keunikan baik dari segi nama, logo, packaging, dan hal lainnya. Sama halnya seperti Madformakeup yang memiliki kesan yang unik dan terdapat makna dalam pemilihan nama yaitu "Madformakeup".

"So basically, Madformakeup start because one day we go to Sephora with my wife and $i$ notice there is something wrong with the pricing of makeup and beauty product. For example beauty blender when I picked it up I know there a volume (kandungan dalam beauty blunder). Volume cannot be 350.000 so I go to the factory, I go to the same place and I understand, "ini bener bener berapa, so I got mad, karena saya dari industri kita untung 1\% atau 2\% tapi keuntungan dia bisa marketing ke semua orang bilang bisa kamu senang, kamu cantik tapi harga dia gasesuai dengan marketing, its not 
very honest. So I decide to make exactly beauty blender and we try five time cheaper and in the first year kita jual 26.000pcs lebih banyak dari beauty blender asli Indonesia, that's all Madformakeup terbuat pada tahun 2017" (Tony, Key informan, 6 Mei, Google Hangouts, Bekasi 2020).

Komunikasi sangat di perlukan bagi perusahaan dalam berinteraksi dengan para karyawan, hal ini bertujuan untuk mendapatkan feedback yang diinginkan atau untuk menngkomunikasikan suatu pesan untuk mencapai tujuan dari suatu perusahaan. Selama pandemi covid-19 perusahaan maupun dunia binis diberlakukan Work For Home. Sehingga komunikasi tetap berjalan melalui berbagai aplikasi.

"In Madformakeup, communication is everything, almost number one one thing, kita selalu berinteraksi dengan para kayawan dan kita selalu open dengan para mahasiswa untuk melakukan interview karena tujuan kita ingin membangun komunitas jadi why communication is important. So that's number one you need to know who you talking to, dan kita berkomunikasi melalu aplikasi untuk in touch dengan karyawan, untuk mengontrol pekerjaan, laporan dan hal lain sebagainya. Sebelum ada pandemic kita lebih banyak berinteraksi secara langsung namun WFH kita pakai aplikasi to connect each other" (Tony, Key informan, 6 Mei, Google Hangouts, Bekasi 2020).

Hal serupa juga dinyatakan oleh key informan lainnya yaitu Damara merupakan bagian dari Marketing Communication.

"Kalau WFH ini kita rutin meeting setiap hari di jam 11 dan ada meeting tambahan di hari jumat untuk semua department. Jadi komunikasi kita selain video call, check up one and other pastikan di group chat, dan kita pakai semacam aplikasi jadi kita bisa connet one to another lewat kerjaan juga, Jadi aplikasi yang bisa control tugas A ini siapa yang in charge." (Damara, Key informan, 20 Mei, Google Hangouts, Bekasi 2020).

Berjalannya suatu bisnis yaitu Madformakeup pasti membutuhkan orang orang yang merealisasikan dalam menjalankan tujuan dari suatu bisnis. Adanya keberhasilan suatu perusahaan tidak luput dari kerjasama dan usaha dari tim yang berada dibalik layar. Mengenai hal ini diperlukan adanya kerjasama serta memotivasi kerja yang berfungsi untuk menjaga, mempertahankan, dan membangun kesolidaritas.

"So this is very difficult, we have to make out team on the same page together that's why daily meeting its very important, so we called it last group Friday meeting, semua department kita ketemu di hari jumat untuk laporan dan kita ada sesi saling mendukung dalam pengerjaan. Seharusnya pada saat ini kita pergi ke bandung bersama sama, mamun karena pandemic 
Rebel Together Sebagai Strategi Komunikasi Pemasaran Digital Madformakeup di Tengah Pandemi COVID-19

covid jadi kita gabisa pergi. Kita juga sering jalan jalan bersama seperti nonton, deep talk." (Tony, Key informan, 6 Mei, Google Hangouts, Bekasi 2020).

Hal yang serupa pun ini didukung juga oleh pernyataan dari key informan lainnya.

"Biasanya tradisi yang di lakukan Madformakeup seperti lauching produk baru biasanya kita akan ada day off setelah launching untuk berlibur untuk para staffnya, misalnya pergi ke Bandung atau sekadar makan dan lain sebagainya. Hal ini dilakukan untuk celebration of oh kita udah sampe sini loh kerjanya kita udah release produk dan lain sebagainya. Lets take break from it for a while. Terus kita jalan annual trip atau biasanya ngerayain staff ulang tahun, intern yang sudah mau selesai. Madformakeup mengambil gaya organisasi seperti kekeluargaan dikarenakan umur staff kita gajauh jadi gaperlu mengambil gaya organisasi yang kaku." (Damara, Key informan, 20 Mei, Google Hangouts, Bekasi 2020)."

Mengembangkan suatu bisnis pasti memiliki suatu pembeda hal ini diberlakukan untuk Madformakeup ditengah persaingan brand komestik lainnya. Hal ini menjadikan sebuah kosmetik memiliki karakteristik tersendiri atau ciri khas yang positif.

"I think you can se from the Madformakeup branding is totally different we are irrelevant, so basically kita tidak perlu pura pura menjadi orang lain, kita bukan dari perusahaan yang kaya. We just have to be ourself, so that very unique point. Kalau kamu penasaran tidak pernah melihat saya di media Madformakeup karena kami ingin kalian beranggapan kalian yang menjalankan company. Karyawan yang paling tertua di Madformakeup adalah umurnya 23 tahun. So this company make product for you because the people inside are like you. Dan fokus kita bukan hanya pada produk saja karena banyak brand diluar sana memiliki kualitas produk yang baik, jadi kita lebih banyak berinteraksi dengan para customer melalui konten Instagram dan mengkomunikasikan selayaknya teman untuk membangun brand community yaitu Rebel Beauty serta menarik engagement tersebut." (Tony, Key informan, 6 Mei, Google Hangouts, Bekasi 2020).

Pernyataan mengenai ciri khas Madformakeup juga dilanjutkan oleh pernyataaan Damara

"Jadi Madformakeup menujukan untuk mengambil ulasan customer yang di mana secara tidak langsung menjadi brand advocate. Madformakeup memiliki brand advocate cukup kuat dan kita tidak ada batasan untuk customer service yang kaku kepada pelanggan. Bahkan sebelum kita mengeluarkan produk Madformakeup selalu membawa value opinion kepada customer 
melalui story Instagram sepeti menanyakan kira kira kita ngeluarin produk ini banyak ga ya yang berminat seperti adanya timbal balik, saat customer merasa di hargai opininya dan ketika kita launching produk pun kita gausah kaya susah untuk marketingnya karena customer yang mau. Jadi keunikan yang dimiliki oleh Madformakeup adalah di brand communitynya jadi Madformakeup punya nama sendiri untuk customernya yaitu Rebel." (Damara, Key informan, 20 Mei, Google Hangouts, Bekasi 2020).

Dunia bisnis online sangat di perlukan dengan adanya strategi komunikasi pemasaran dikarenakan banyak pesaing brand komestik lokal memasarkan produknya melalui online, adanya strategi komunikasi pemasaran yang baik maka akan menghasilkan tujuan yang ingin di capai yaitu berhubungan baik dengan pelanggan. Dengan adanya hubungan yang baik dengan pelanggan melalui strategi komunikasi maka akan membentuk kepercayaan atau loyalitas terhadap produk Madformakeup.

"Of course its really important, seperti yang saya sudah bilang banyak pesaing diluar sana dan tentu memiliki produk yang bagus gaada perusahaan yang memiliki produk yang jelek, dan sekarang tahun 2020 untuk menarik engagement di bisnis online ini sangat di perlukan bukan lagi bicarakan soal produk, hal ini ditujukan untuk menjaga loyalitas terhadap pelanggan." (Tony, Key informan, 6 Mei, Google Hangouts, Bekasi 2020).

Hal serupa juga di nyatakan oleh Damara Marketing Communication Madformakeup

"Penting banget untuk bisnis online karena Madformakeup belum ada offline storenya, menurut aku penting banget adanya strategi karena banyak pesaing yang muncul, maka dari itu penting untuk keep customer untuk loyal sama Madformakeup dengan cara jaga komunikasi yang strategis sama customer agar mereka tahu kalau Madformakeup masih valuable untuk dijadikan priorty untuk repurchase selanjutnya." (Damara, Key informan, 20 Mei, Google Hangouts, Bekasi 2020)".

Pernyataan dari sisi key informan ini pun dapat dikuatkan dengan adanya pernyataan yang diberikan oleh salah satu pelanggan sebagai informan pendukung yang merupakan cutomer Madformakeup yang bernama Daniella

"lumayan loyal, karena aku baru tau Madformakeup akhir - akhir ini, gatau kenapa setiap Madformakeup ngeluarin produk baru pokoknya aku harus punya, soalnya aku pernah coba salah satu produknya terus suka, terus coba yang lainnya ternyata semuanya cocok, jadinya beli terus." (Daniella, Informan pendukung, 27 Mei, Google Hangouts, Bekasi 2020).

Mengembangkan suatu bisnis sudah menjadi keharusan untuk mengetahui 
dan menetapkan segementasi maupun target dari Madformakeup. Adanya suatu target dan segmentasi dapat mengukur suatu bisnis dalam menentukan siapa yang akan menjadi tujuan pelanggan. Madformakeup memiliki segmentasi dan targetnya tersendiri dalam memasarkan produknya. Mengenai hal ini maka Madformakeup dalam memasarkan produknya dapat tepat targetnya dan kemungkinan dalam mencapai keberhasilan akan lebih besar.

"Segmen market terbesar kita di umur 20 - 24 tahun, karena mereka paling aktif di social media, dan produk kita memang ditujukan untuk Mahasiswa atau bisa dibilang yang baru belajar makeup. Secara geografis seluruh Indonesia, karena kita promosi melalui online jadi pengiriman produk sudah gampang. Sesuai dengan visi kita yaitu beauty prices make sense, semua wanita cantik dan itu sudah menjadi hak dasar. Disini kita ingin menyampaikan bahwa cantik itu bukan berarti harus mengeluarkan banyak uang. Karena banyak brand mempopulerkan bahwa wanita bisa cantik tapi dengan harga yang tidak make sense. Jadi Madformakeup hadir dengan harga yang masuk akal dan bisa mempunyai kualitas yang bagus juga." (Tony, Key informan, 6 Mei, Google Hangouts, Bekasi 2020)

Pernyataan dari Tony dinyatakan kembali oleh Damara bahwa target segmentasi mengarah pada hal yang sama

"Sebenernya Madformakeup itu secara demografis early 20 - 24 itu pasar terbesarnya Madformakeup karena mereka cepet bgt tanggep dengan trend yang ada. Geografis kita Jabodetabek dan kota besar lainnya, Kalo psikografis Madformakeup ditujukan bukan untuk digunakan pro makeup artist tetapi penggunaan makeup yang digunakan sendiri. Madformakeup ditujukan untuk wearable setiap hari dan gasusah dalam pemakaiannya seperti lipstick 3in1 Effortless ga hanya di pake bibir tapi bisa dijadiin eyeshadow dan juga blush. Jadi Madformakeup ingin mempositioning kan bahwa cantik gaperlu yang mahal, semua perempuan itu cantik. Dan penggunaan makeup yang wearable gaperlu ribet." (Damara, Key informan, 20 Mei, Google Hangouts, Bekasi 2020)"

Pernyataan yang serupa juga di nyatakan oleh pelanggan Madformakeup yaitu Daniella bahwa produk Madformakeup sesuai dengan targetnya.

"Awalnya aku coba Highlighternya karena sebenernya produknya lumayan bagus, terus aku penasaran lagi pengen coba produk lain, nah ternyata setelah aku cobain lipsticknya aku suka juga, beauty blender dan lain sebagainya semuanya aku suka dan belum ada yang gacocok di aku. Madformakeup kaya tau target aku gitu" (Daniella, Informan pendukung, 27 Mei, Google Hangouts, Bekasi 2020).

Strategi komunikasi pemasaran yang digunakan perusahaan tentu 
mengalami perubahan seiring berjalannya perkembangan trend. Bukan hanya mengikuti trend tetapi di tahun 2020 seluruh dunia menghadapi pandemi covid19 termasuk Indonesia, hal ini berdampak pada perubahan sistem strategi komunikasi yang dilakukan oleh perusahaan untuk bertahan ditengah pandemic ini, hal ini pun berdampak pada perusahaan Madformakeup dalam mengubah strategi komunikasi pemasarannya yang bertujuan untuk bertahan dalam menjalankan suatu bisnis.

"Yes mengalami perubahan. Pada awalnya kita melakukan komunikasi pemasaran yang berfokus pada product berubah menjadi komunikasi yang berfokus pada komunitas, kami menghabiskan lebih sedikit untuk Key Opinion Leader atau biasa disebut influencer dan Ads, Lebih fokus pada penyediaan konten yang bermanfaat dan mendukung untuk membangun melalui Instagram konten kita disebut \#RebelTogether." (Tony, Key informan, 6 Mei, Google Hangouts, Bekasi 2020).

Hal yang serupa mengenai perubahan strategi komunikasi selama pandemi covid-19 juga di nyatakan oleh Damara

"Tentu mengalami perubahan, waktu awal masuk WFH kita launching produk skincare Poreless lalu kita reconsider strateginya dalam masa pandemi memikirkan untuk membuat strategi yang baru dan pandemi ini bisa kita jadikan opportunity untuk kedepannya, akhirnya kita launching projek perdana yaitu Rebel Togther sekitar 1 Mei kemarin untuk memperkuat brand community hal ini untuk berstrategi bertahan di masa pandemic ini bukan hanya fokus pada produk jadi kta fokus pada kebutuhan customer, Rebel Together ada T-Shirt Competition, lalu kita buka kelas Marketing Branding, mendapatkan giveaway star pimple patch, kompetisi Rebel Queen, ada donasi dan lain lain, banyak kegiatan yang kita lakuin di Mei sampai Juni ini. Jadi hal ini berfungsi untuk plot bakal release produk untuk kedepannya sehingga Rebel Together befungsi untuk strength brand community dan di harapkan nantinya sesudah pandemi selesai customer dapat put on trust terhadap Madformakeup. Madformakeup juga menaro invest kepercayaan mereka melalui Rebel Together dengan berbagai opsi kompetisi. Sebelum pandemic kita juga aktif di Instagram story buat konten, semenjak ada pandemic ini kita semakin aktif untuk buat konten di Instagram story jadi komunikasi yang dibawakan adalah kita membuat timline staffnya untuk handle Instagram. Contohnya aku hari ini di tugaskan untuk buat konten Instagram yang releateable di kehidupan sehari hari ga hanya ngomongin soal produk,promosi, dan lain sebagainya. Tapi kita juga menarik buat main games." (Damara, Key informan, 20 Mei, Google Hangouts, Bekasi 2020)”.

Penyampaian suatu strategi komunikasi pemasaran membutuhkan channel dari segi online maupun offline dalam menyebarkan suatu informasi atau pesan yang 
ingin disampaikan oleh perusahaan agar tujuan dari perusahaan dapat tercapai, hal ini dilakukan oleh Madformakeup dalam memperkenalkan produknya melalui digital atau online yang ditujukan kepada customer dengan melalui berbagai channel.

"We are using Instagram, E-commerce, Facebook untuk ads, dan baru baru ini kita buat Tiktok, Instagram merupakan salah satu channel utama kita untuk memberikan informasi mengenai Madformakeup mulai dari informasi produk, berinteraksi dengan customer, membangun komunitas dll, alasan memilih media tersebut karena di umur kalian masih ingin explore dalam segala hal, dan terus ingin mencari sesuatu yang baru." (Tony, Key informan, 6 Mei, Google Hangouts, Bekasi 2020).

Madformakeup dalam menyampaikan pesan melalui berbagai platform digital juga dinyatakan oleh Damara selaku Marketing Communication Madformakeup

"Yang paling utama digunakan Madformakeup Instagran, sebenernya website itu kita gapake buat dijadiin e-commerce. Jadi website itu cuman platform informasi untuk lowongan internship, atau informasi seputar project yang sedang berjalan seputar RebelTogther, kalau misalkan facebook kita hanya gunakan untuk ads, di twitter kita aktif, dari awal Maret kita juga gunain Tiktok untuk sebagai konten. Itu merupakan salah satu strategi kita membuat Madformakeup accessible buat semua orang untuk reach out. Kalau e-commerce yang official kita ada Shopee, Sociolla, Tokopedia dan lain sebagainya kita kuat di platform tersebut karena customer belanja disitu. Karena kita kan relaynya lewat didigital marketing jadi kita pengen semua orang bisa akses di jalur mana aja." (Damara, Key informan, 20 Mei, Google Hangouts, Bekasi 2020)

Pernyataan dari Tony dan Damara didukung juga oleh Pelanggan dari Madformakeup yaitu Daniella. Daniella mengetahui produk dan melakukan transaksi produk Madformakeup melalui media online.

"Dari Instagram, Biasanya belanja produknya di official Shopee Madformakeup, tapi kalo ada diskon aku beli di Sociolla, paling sering di Shopee". (Daniella, Informan pendukung, 27 Mei, Google Hangouts, Bekasi 2020).

Memberikan informasi kepada customer untuk melakukan transaksi melalui e-commerce diperlukan adanya strategi komunikasi untuk menuntun dalam transaksi online. Madformakeup mengarahkan customer melalui fitur Instagram dalam proses melakukan transaksi online di Shopee sehingga memudahkan customer dalam melihat harga produk hingga melakukan transaksi online.

"Oh oke jadi di Instagram Madformakeu.co ada tanda shop disana, jadi kalau di klik muncul harga per produknya, dan customer diarahkan ke e- 
Indri Julianti \& Santi Delliana

commerce kita yaitu Shopee." (Tony, Key informan, 6 Mei, Google Hangouts, Bekasi 2020).

Hal senada juga dinyatakan oleh key informan lainnya yaitu Damara bahwa alur transaksi online e-commerce Shopee telah disediakan melalui Instagram

"Karena channel utama kita di Instagram jadi kita memberikan informasi melalui Instagram untuk connect langsung ke Shopee, ada tampilannya di Instagram tanda Shop bahkan ada harganya jadi udah detail dan di shopee juga lebih lengkap untuk produknya. Kalau di Shopee saat produk udah masuk di situs untuk packingnya di warehouse kita, kalau di warehouse kita punya packaging yang lebih banyak diminati customer karena kita kasih permen kaki, beda dengan Sociolla karena mereka beli dari warehouse kita jadi pacakagingnya sesuai dengan khasnya yang berwarna pink." (Damara, Key informan, 20 Mei, Google Hangouts, Bekasi 2020).

Hasil dari wawancara, peneliti menyimpulkan bahwa Madformakeup menerapkan strategi komunikasi pemasaran digital yang berbeda, dengan menfokuskan dalam membangun brand community dari pada fokus pada produk selama pandemi covid-19, sehingga menghasilkannya kenaikan dalam menarik customer engagement.

Hasil observasi yang dilakukan peneliti melalui media sosial Instagram Madformakeup meliputi kegiatan program Rebel Together selama pandemi covid-19 pada tanggal 22 April-30 Mei 2020, peneliti juga melakukan observasi ketika wawancara online melalui zoom. Observasi yang dilakukan peneliti melalui media sosial Instagram berupa unggahan gambar kegiatan progam strategi komunikasi pemasaran, yaitu konten Rebel Together di Instagram @Madformakeup.co (Instagram Madformakeup, 2020) sehingga hasil kegiatan program Rebel Together menghasilkan kenaikan engagement, pada awalnya 1,95\% menjadi $2,56 \%$.

Hasil dokumentasi dari penelitian ini adalah unggahan gambar progam strategi komunikasi pemasaran, yaitu Rebel Together di Instagram @,Madformakeup.co. 
Rebel Together Sebagai Strategi Komunikasi Pemasaran Digital Madformakeup di Tengah Pandemi COVID-19

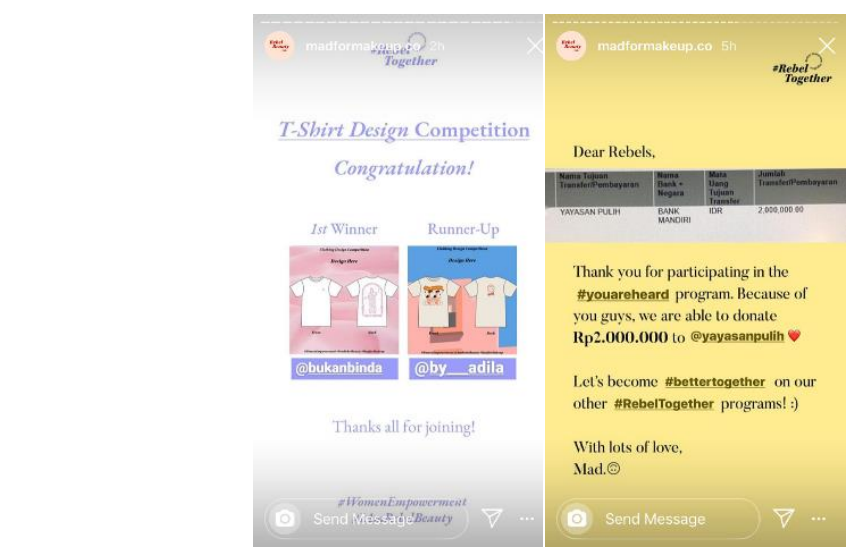

Sumber: (Instagram Madformakeup, 2020)

Gambar 1. Program Rebel Together

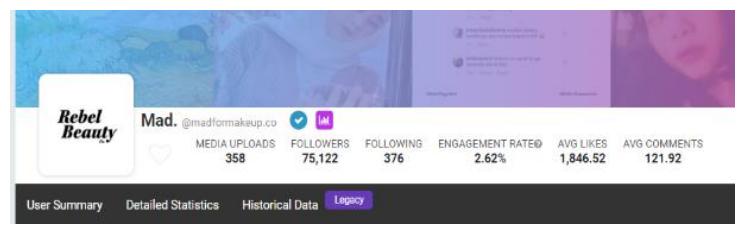

Sumber: (Instagram Madformakeup, 2020)

Gambar 2. Hasil Engagement Madformakeup

\section{Strategi Komunikasi Pemasaran}

Madformakeup selama pandemi covid-19 melakukan perubahan perancangan terhadap strategi komunikasi pemasaran dengan mengembangkan ide baru, hal ini bertujuan untuk mempertahankan suatu bisnis di tengah pandemi covid-19. Madformakeup melakukan perubahan strategi komunikasi pemasaran digital yang di mana sebelum pandemi fokus kepada produk. Adanya pandemi covid-19 Madformakeup membuat ide baru dengan memfokuskan strategi komunikasi kepada komunitas melalui konten Rebel Together. Madformakeup menyampaikan dan melaksanakan kegiatan tersebut melalui media sosial Instagram dan mendapatkan feedback ulasan positif dari pelanggan dengan adanya ulasan positif dari pelanggan terjadinya ketertarikan pelanggan terhadap brand Madformakeup dalam pemutusan pembelian produk. Program Rebel Together diselenggarakan pada saat pandemi covid-19 yaitu 1 Mei 2020. Kegiatan tersebut berupa donasi, kompetisi (T-Shirt Competition), Marketing Branding Online, membuat konten yang berkaitan dengan kehidupan sehari-hari, hal ini berfungsi untuk meningkatkan dan memperkuat brand community serta dapat meningkatkan loyalitas konsumen terhadap Madformakeup. 
Strategi komunikasi melalui internal juga dibutuhkan, demi menjaga kesolidaritas tim dan menjaga kerjasama yang baik. Hal ini memiliki peranan dalam membangun kesuksesan tim Madformakeup. Terlebih cara mengkomunikasikan suatu pesan antara manajemen dan stafnya dikenal dengan menggunakan bahasa yang tidak kaku namun namun tetap sopan selayaknya beinteraksi dengan teman sendiri, dikarenakan staf yang bekerja di Madformakeup dari segi umur anak muda, staf yang tertua berumur 24 tahun. Selama pandemi covid-19 Madformakeup tetap melakukan Work for Home (WFH) dan berkomunikasi (rapat) melalui aplikasi yang dilakukan setiap hari pada pukul 11 siang. Setiap hari Jumat diadakan weekly meeting yang diikuti semua departemen. Di penghujung acara dilakukan sesi saling mendukung satu sama lain. Demi membangun kerjasama dengan adanya interaksi yang baik. Upaya memotivasi kerja juga dilakukan Madformakeup untuk para stafnya seperti kegiatan nonton bersama, deep talk dalam rangka menjalin ikatan personal yang baik. Ketika launching produk baru, para staf diajak turut serta keluar kota sebagai salah satu bentuk penghargaan karena tim Madformakeup telah bekerja keras untuk membangun Madformakeup. Komunikasi yang direncanakan sangat diperlukan juga untuk eksternal Madformakeup yaitu pelanggan. Adanya strategi komunikasi yang baik dan efektif akan menghasilkan hasil yang baik juga terhadap perusahaan. Penggunaan e-marketing merupakan kegiatan promosi yang di lakukan melalui media internet dikarenakan tingkat efektifitas yang tinggi dari internet dapat membantu pemasaran.

\section{Komunikasi Melalui Strategi Pemasaran}

Adanya strategi pemasaran yang akan membantu pelaku bisnis dalam menunjukan dan merincikan pemasaran yang tepat sesuai dengan target produk yang akan dipasarkan. Madformakeup menggunakan konsep strategi pemasaran yaitu STP. Madformakeup akan dapat menjalankan pemasaran yang berjalan sesuai arah tujuan yang telah ditentukan.

Segmentasi

Madformakeup memiliki segmentasinya sendiri, yang dapat dijabarkan melalui tabel berikut.

\section{Tabel 1. Segmentasi Madformakeup}

\begin{tabular}{|c|c|c|}
\hline \multicolumn{3}{|l|}{ Segmentasi } \\
\hline Demografis & Geografis & Psikografis \\
\hline 20-24 Tahun & $\begin{array}{l}\text { Paling besar sejabodetabek, } \\
\text { tetapi bisa satu Indonesia } \\
\text { dikarenakan } \\
\text { online }\end{array}$ & $\begin{array}{l}\text { Pelanggan yang baru mencoba } \\
\text { makeup, penggunaan produk } \\
\text { yang wearable, harga produk } \\
\text { yang masuk akal }\end{array}$ \\
\hline
\end{tabular}


Berdasarkan tabel 1 dapat dilihat adanya pengelompokan yang terbagi atas tiga variabel, dalam demografis, Madformakeup memilih anak muda dikarenakan dalam memasarkan produknya melalui internet marketing khususnya social media. Di umur 20-24 tahun sangat aktif dalam social media, dan produk Madformakeup ditujukan untuk kalangan anak muda. Pemilihan geografi Madformakeup sejabodetabek, namun tidak menutup kemungkinan bisa mencapai se-Indonesia dikarenakan promosi yang dilakukan Madformakeup melalui online sehingga jangkauan lebih luas, dan proses pengiriman produk sudah dimudahkan.

Targeting

Madformakeup memliki targetnya tersendiri hal ini untuk memfokuskan dalam memasarkan produk sehingga dapat menargetkan calon pelanggan yang akan dituju, dapat dirincikan pada tabel berikut:

Tabel 2 Targeting Madformakeup

\begin{tabular}{lll}
\hline Pelanggan & Usia & Pekerjaan \\
\hline Anak Muda & 20 tahun -24 tahun & $\begin{array}{l}\text { Pelajar, Mahasiswa/I, First } \\
\text { Jobber }\end{array}$ \\
\hline
\end{tabular}

Madformakeup memfokuskan targetnya yaitu anak muda di usia 20-24 tahun yang meliputi pelajar, mahasiswi, dan first jobber karena anak muda cepat tanggap mengenai trend yang ada dan anak muda sangat aktif dalam menggunakan media sosial dan ingin mencoba segala sesuatu yang baru dan ingin mencoba segala sesuatu produk makeup.

Positioning

Madformakeup mencoba menanamkan perbedaan dengan brand kosmetik lainnya mulai dari ciri khas, dan daya tariknya Ketika brand kosmetik lainnya membicarakan bahwa semua wanita itu cantik tetapi produk yang ditawarkan mahal dan tidak masuk akal, Madformakeup mencoba memposisikan brandnya bahwa menjadi cantik tidak harus mahal, beauty is right, dan Madformakeup ingin mendemokrasikan produk dengan harga yang masuk akal dan tetap memiliki kualitas pada produknya. Madformakeup ingin memperkenalkan dalam menggunakan produknya tidak perlu susah dalam penggunaanya. Makeup Madformakeup dapat digunakan sehari-hari dan wearable.

\section{Integrated Marketing Communication}

Madformakeup melakukan usaha dalam mempromosikan produknya kepada publik termasuk para pelanggan dengan yang merupakan ramuan dari berbagai unsur-unsur promosi yang ada didalamnya.

Madformakeup memanfaatkan iklan/advertising melalui media sosial yaitu Instagram Ads yang dipergunakan untuk mengiklankan melalui Instagram story dan 
Indri Julianti \& Santi Delliana

feeds mengenai campaign yang dibuat atau launching produk terbaru, dan melakukan key opinion leader atau yang dikenal influencer ketika launching produk influencer dapat meulasan produk terbaru, hal ini bisa berdampak pada ketertarikan customer engagement dalam meningkatkan penjualan terhadap produk Madformakeup.

Madformakeup mengadakan promosi penjualan dalam bentuk potongan harga dihari spesial seperti saat Ramadhan Sale, Madformakeup juga melakukan beberapa kegiatan kontes selama pandemi covid-19. Salah satunya kompetensi yang dilakukan Madformakeup adalah berkolaborasi dengan brand kosmetik lainnya. Hadiah yang didapatkan ditujukan untuk para pelanggan yang mengikuti kontes atau permainan.

Kegiatan kehumasan yang dilakukan Madformakeup selama covid-19 adalah kegiatan donasi dalam hal kemanusiaan untuk membantu sesama. Seperti terjadinya pandemi covid-19. Madformakeup berperan dalam membantu rumah sakit RSUD Cengkareng dan menggalang dana dengan mengajak pelanggan Madformakeup untuk berpartisipasi dalam membantu sesama ditengah wabah ini dengan cara setiap pembelian poreless essence 3in1 50\% akan disumbangkan ke rumah sakit tersebut. Madformakeup juga memiliki kegiatan event yang diselenggarakan online melalui media sosial Instagram. Program ini disebut Rebel Together, T-shirt Design Competition, Rebel Queen.

Madformakeup melakukan penjualan secara personal atau personal selling secara online dikarenakan Madformakeup tidak memiliki offline store. Dalam elemen kegiatan memromosikan ini juga Madformakeup memberikan produk sampel yang ditujukan langsung ke pelanggan yang mengalami kebingungan terhadap pemilihan shade produk.

Madformakeup bukan ditujukan untuk aktivitas promosi. Tetapi e-mail digunakan untuk pelanggan yang ingin mengajukan pertanyaan tentang Madformakeup atau melakukan perizinan, serta mengajak berkolaborasi dengan brand lainnya.

Madformakeup melangsungkan kegiatan pemasaran interaktif melalui media social (Interactive Internet Marketing) seperti Instagram, Twitter, Website Official dan Youtube. Walaupun belum berjalan secara aktif pada media sosial Youtube, maupun websitenya untuk melakukan transaksi, namun Madformakeup terus melakukan upaya dalam pengelolaan agar dapat menjadi salah satu media aktif yang digunakan Madformakeup.

\section{Customer Engagement}

Kegiatan customer engagement sangat diperlukan bagi suatu perusahaan hal ini bertujuan untuk berinteraksi dengan pelanggan sehingga dapat menimbulkan adanya kegiatan pembelian. Perusahaan Madformakeup menerakapkan kegiatan customer engagement melalui program Rebel Together. Kegiatan Rebel Together selama pandemi covid-19 dilakukan melalui Instagram. Kegiatan tersebut berisikan 
pembuatan konten yang berkaitan dengan kehidupan sehari-hari melalui Instagram story dengan mengajak para pelanggan untuk berinteraksi melalui $Q \circlearrowleft \mathrm{A}$ dan games. Rebel Together juga melakukan kegiatan donasi saat covid-19 muncul dengan mengajak pelanggan setiap pembelian produk 3 in 1 essence sebesar 50\% akan didonasikan ke RSUD Cengkareng. Rebel Together juga melakukan berbagai kegiatan kompetensi selama pandemi covid-19 yaitu membuka kelas online Marketing Branding, serta kompetensi Rebel Queen, dan yang terakhir adalah T-shirt Design Competition.

Menurut Jaakola \& Alexander (2014, p. 248) customer engangement merupakan perilaku konsumen yang dapat memberikan kontribusi secara sukarela melalui transaksi, memberikan feedback dalam bentuk saran atau ide, dan word of mouth. Berjalannya program Rebel Together perusahan Madfromakeup mendapatkan ulasan positif dari pelanggan secara keseluruhan membuahkan hasil yang positif. Penerapan strategi komunikasi pemasaran dalam customer engagement Madformakeup selama covid-19 mengalami peningkatan terhadap engagement Instagram. Keberhasilan ini dinyatakan oleh Tony selaku Business Development Manager bahwa engagement di Instagram mengalami kenaikan pada awalnya 1,95\% menjadi 2,56\% dibandingkan dengan brand kosmetik lainnya yaitu BLP Beauty selama pandemi covid-19 hanya mencapai $0,51 \%$. Peneliti melakukan pengecekan kembali pada tanggal 1 Juni dengan membuka $W$ eb Social Blade dan membandingkan dengan brand kosmetik BLP Beauty untuk memastikan Madformakeup mengalami kenaikan engagement dan terjadi peningkatan dalam engagement. Mengenai hal ini Madformakeup berhasil dalam menerapkan strategi komunikasi pemasarannya sehingga dapat menarik konsumen melalui konten dan program Rebel Together. Pernyataan ini dikuatkan oleh informan pendukung yaitu Daniella sebagai Customer Madformakeup yang di mana dia sangat menyukai konten yang dibuat oleh Madformakeup dikarenakan relate dengan kehidupan sehari-hari sehingga tidak bosan, lalu program Rebel Together sangat menarik untuk diikuti seperti kompetensi Rebel Queen ini.

Adanya ulasan positif secara sukarela dari para pelanggan dapat memberikan dampak terhadap brand Madformakeup secara positif. Serta berdasarkan data dari Zap Beauty bahwa ulasan produk kecantikan sebesar 64,7\% dapat memberikan dampak pada wanita dalam memutuskan membeli sebuah produk kecantikan. Hal ini sangat berpengaruh pada generasi Z rentang usia 13-22 Tahun. Madformakeup melakukan kegiatan customer engagement sehingga mendapatkan ulasan positif bukan hanya melalui Instagram saja tetapi berbagai platform seperti Instagram, Shopee, Tokopedia, dan Sociolla.

Madformakeup menerapkan strategi komunikasi pemasaran hal ini bertujuan untuk menarik customer engagement sehingga mendapatkan feedback yang positif melalui ulasan dari berbagai customer secara sukarela, dengan adanya ulasan positif dari customer secara sukarela dapat mencerminkan bahwa produk memiliki kualitas 
yang bagus, serta dapat memengaruhi pelanggan dalam memilih suatu produk. Maka dengan hal ini dapat memberikan dampak positif dalam meningkatkan penjualan produk.

\section{PENUTUP}

Madformakeup mengalami perubahan strategi komunikasi pemasaran digital selama pandemi covid-19. Awalnya Madfromakeup hanya berfokus pada produk saja lalu memfokuskan dalam membangun komunitas melalui program Rebel Together. Strategi komunikasi pemasaran dalam mengkomunikasikan suatu pesan yang diterapkan Madformakeup tidak kaku dan bersifat friendly baik melalui internal dan eksternal (pelanggan).

Penerapan strategi komunikasi pemasaran terkait segmentasi, targeting, dan positioning. Berdasarkan tiga elemen ini berhasil ditetapkan oleh Madformakeup sesuai dengan target pelanggan Madformakeup sehingga dapat menarik minat pelanggan terhadap pembelian produk. Positioning yang dilakukan Madformakeup juga baik dalam penyampaian pesan kepada pelanggan mengenai daya tarik dan ciri khas sebagai pembeda brand kosmetik ditengah ramainya pasar bisnis kosmetik lokal. Dari setiap elemen konsep IMC yang dilaksanakan Madformakeup selama pandemi covid-19 ini, tentu terdapat kegiatan yang sering dilakukan dan jarang dilakukan. Dalam hal ini, media sosial Instagram merupakan kegiatan utama yang sering dilakukan Madformakeup serta kegiatan public relations yang juga sering dilaksanakan ditengah pandemi ini. Kegiatan yang jarang dilakukan selama pandemi covid-19 adalah advertising, iklan tetap berjalan namun mengurangkan lebih sedikit, dan elemen direct marketing tidak diterapkan Madformakeup. E-mail yang digunakan bukan untuk promosi melainkan sebagai informasi untuk berinteraksi dengan Madformakeup.

Program Rebel Together berhasil mengalami peningkatan dalam engagement. Pada awalnya 1,95 menjadi 2,56\%. Dampak positif dapat dilihat dari banyaknya tag-an mengenai ulasan positif terhadap Madformakeup, banyaknya interaksi yang dilakukan melalui komentar feeds Instagram, direct message. Dengan adanya citra dan ulasan yang positif dapat memberikan dampak terhadap menarik minat pelanggan terhadap pembelian. Saran peneliti adalah dengan mengembangkan brand Madformakeup secara dengan membuka offline store. Membuat dan merencanakan program baru dalam komunikasi pemasaran seperti membuat konten yang menarik melalui youtube.

\section{DAFTAR PUSTAKA}

Afrilia, A. M. (2018). Digital Marketing Sebagai Strategi Komunikasi Pemasaran "Waroenk Ora Umum" Dalam Meningkatkan Jumlah Konsumen. Jurnal Riset Komunikasi (JURKOM), 1(1), 147-157. https://doi.org/https://doi.org/10.38194/jurkom.v1i1.21 
Rebel Together Sebagai Strategi Komunikasi Pemasaran Digital Madformakeup di Tengah Pandemi COVID-19

Andriansyah. (2020). Memotret Strategi Komunikasi Pemasaran Terintegrasi Pada

Industri Fashion. Jurnal Manajemen Bisnis, 17(2), 360-373. https://doi.org/https://doi.org/10.38043/jmb.v17i3.2521

Boer, K. M., Pratiwi, M. R., \& Nalal, M. (2020). Analisis Framing Pemberitaan Generasi Milenial dan Pemerintah Terkait Covid-19 di Media Online. Communicatus: Jurnal Ilmu Komunikasi, 4(1). https://doi.org/10.15575/cjik.v4i1.8277

Cangara, H. (2014). Perencanaan dan Strategi Komunikasi. Rajawali Pers.

Delliana, A. S., \& Wibowo, A. M. (2019). Bigo Live: Ethical Degradation in Communication (A Critical Study of Communication in a ComputerMediated Communication Perspective). Proceedings of the Tarumanagara International Conference on the Applications of Social Sciences and Humanities (TICASH 2019).

https://doi.org/https://dx.doi.org/10.2991/assehr.k.200515.015

Instagram Madformakeup. (2020). https://www.instagram.com/madformakeup.co/ Jaakkola, E., \& Alexander, M. (2014). The Role of Customer Engagement Behavior in Value Co-Creation A Service System Perspective. Journal of Service Research, 17(3), 247-261.

Jatmiko, A. (2020). SurveySensum: Pelaku Usaha Fokus Promosi Digital Saat Pandemi Covid-19.

Www.Katadata.Co.Id.

https://katadata.co.id/berita/2020/04/20/surveysensum-pelaku-usaha-

fokus-promosi-digital-saat-pandemi-covid-19

Kemenperin. (2020). Perubahan Gaya Hidup Dorong Industri Kosmetik.

Www.Kemenperin.Go.Id.

Lalu, R. (2020). Pebisnis mulai mengencangkan ikat pinggang. Www.Lokadata.Id.

Morissan. (2010). Periklanan: Komunikasi Pemasaran Terpadu. Kencana Prenada Media Group.

Mulyadi, S. (2013). Metode Penelitian Kualitatif dan Mixed Method. Pena Press.

Putri, S. R. (2020). 5 Alasan Perempuan Indonesia Kian Memperhatikan Produk Skincare.

Www.Cantika.Com. https://www.cantika.com/read/1298310/5-alasanperempuan-indonesia-kian-memperhatikan-produk-skincare

Sugiyono. (2016). Metode Penelitian Kuantitatif, Kualitatif, dan R\&D. Alfabeta.

Teguh, M., Widjaja, E. D. N., Hartanto, L. C., \& Lukito, osephine K. (2020). Implementation of Integrated Marketing Communication at Kampoeng Semarang. Proceedings of the 2nd Jogjakarta Communication Conference (JCC 2020). https://doi.org/https://dx.doi.org/10.2991/assehr.k.200818.051

Theresiana, L., \& Setyanto, Y. (2018). Strategi Komunikasi Pemasaran yang Dilakukan Guten Morgen Coffee Lab and Shop untuk Menarik Konsumen. Jurnal Prologia, 2(2), 392-399. https://doi.org/http:/ /dx.doi.org/10.24912/pr.v2i2.3717

Wardana, W. (2017). Strategi Pemasaran. Deepublish. 
Indri Julianti \& Santi Delliana

Willems, H. (2011). Transitioning into A Blueconomy. White Paper Customer Driven Online Engagement. 